\title{
Evaluation of the Relationships between Urban Infrastructure and Flood Disaster in Gombe Metropolis
}

\author{
Dabara Ibrahim Daniel $^{1}$, Okorie Augustina ${ }^{1}$, Ankeli Anthony $^{1} \&$ Alabi Jimoh Kayode ${ }^{1}$ \\ ${ }^{1}$ Estate Management Department, Federal Polytechnic Ede, Osun State, Nigeria \\ Correspondence: Dabara Ibrahim Daniel, Estate Management Department, Federal Polytechnic Ede, PMB 231, \\ Ede, Osun State, Nigeria. Tel: 234-802-561-5074. E-mail: dabara2000@yahoo.com
}

Received: May 4, 2012 Accepted: June 7, 2012 Online Published: June 28, 2012

doi:10.5539/jsd.v5n7p137

URL: http://dx.doi.org/10.5539/jsd.v5n7p137

\begin{abstract}
The purpose of this study is to evaluate the relationship between urban infrastructure and flood disaster in Gombe metropolis, Nigeria. In this research work, the survey research design was used to obtain data from the field. Stratified sampling technique was adopted in determining the study sample which consisted of 250 households (i.e. $13 \%$ of the population, made up of 1,923 households). 250 questionnaires were administered on household heads in the study area; however, only 237 questionnaires were retrieved and used for analysis. Spearman's rank correlation and multiple linear regression analysis were used to examine the relationships between the criterion variable (flood disaster) and the predictor variables (urban infrastructure). The study showed that inadequacy of appropriate urban infrastructure is the major factor responsible for flood disaster in Gombe metropolis $[\mathrm{R}=0.792, \mathrm{P}=0.000<0.01$ (2-tailed)]. It was recommended among others, that there should be improvement on the maintenance of available drainage infrastructure in the metropolis and the integration of solid waste management to prevent over flowing of flood as a result of blockage of drains. Government and all other stakeholders should expedite the provision of appropriate urban infrastructure in the metropolis.
\end{abstract}

Keywords: urbanization, flood disaster, urban infrastructure, sustainability

\section{Introduction}

Urban infrastructure can be generally defined as the set of interconnected structural elements that provide framework supporting an entire structure of development, it consist of basic physical and organizational structures needed for the operation of a society or enterprise that provides services essential to enable, sustain, or enhance societal living conditions (Brooks, 2003; IPCC, 2007). A number of research studies have been undertaken in the recent past on various aspects of infrastructure and its effects on development (Bond Gary, 1994; Chandavarkar, 1994; Kohli, 1994, 1995; Jha, 1995; GOI, 1996; Nayak, 1999). Infrastructure is one of the indispensable elements in the process of urbanization and emergence/continuity of an urban growth. It is considered as motor/engine for economic development (Dagnachew, 2011). In situations where urbanization is not matched with corresponding urban infrastructure, hazards such as flood disaster are often inevitable. Flood disaster by nature are complex events caused by a range of human vulnerabilities, inappropriate development planning and climate variability (Olorunfemi, 2008). Generally, it is attributed to global warming, climate change, ocean swell/surge and torrential rains. Although flood hazards are natural phenomena, damage and lose from floods are mostly the consequences of urbanization without corresponding infrastructural restructuring (Brooks, 2003). Normal floods are expected and generally welcomed in many parts of the world as they provide rich soil, water and a means of transport, but flooding at an unexpected scale and with excessive frequency causes damage to life, livelihoods and the environment (IPCC, 2007). Hence, a solution to curbing this menace, will mean saving of millions of lives and properties. Over the past decades, the pattern of floods across all continents has been changing, becoming more frequent, intense and unpredictable for local communities, particularly as issues of development and poverty have led more people to live in areas vulnerable to flooding. The Fourth Assessment Report of the Intergovernmental Panel on Climate Change IPCC (2007) predicts that heavy precipitation events, which are very likely to increase in frequency, will augment flood risk.

The problem of flood in Nigeria and particularly in Gombe has spanned over a long period, and is associated with many factors. Among these factors are the increase in population and rapid urbanization aggravated by urban sprawl, unplanned development, overgrazing, excessive land cultivation and inadequate urban 
infrastructure. Despite the efforts made by Government, Individuals, Non-governmental organizations and International donor agencies, the problem of flood is increasing rapidly in Gombe. The world Bank, in its effort to assist the state in mitigating flood disaster in the year 2000 embarked on the construction of drainages in GRA, Pantami, Madaki, Yelwan Bogo/BCGA, Sabon Layi and Herwagana. In 2005/2006 SARPLAST was awarded the contract for the construction of drainages in: FMC road/Federal Lowcost/Checheniya and Buba Shongo/Jekadafari/Kumbiya-kumbiya. Despite all the efforts stated above, the problem still persists.

The major purpose of this study is to identify the major cause(s) of flood disaster in the study area, through a critical analysis of the relationships of urban infrastructure and flood disaster in Gombe metropolis. Data for the study was obtained from questionnaire survey in the study area. The availability of such data provides a unique opportunity to relate the relationships between urban infrastructure and flood incidences in Gombe metropolis empirically. In this respect, the paper addresses the following questions: What are the factors responsible for flood disaster in the study area? What is the relationship between urban infrastructure and urban flood disaster in the study area? The answers to these questions are pivotal to identifying factors responsible for urban flood disaster in Gombe metropolis as well as provision of viable solution to the unpalatable menace of flood disaster in the study area particularly and other similar areas in Africa and beyond. The paper is divided into six sections: The introduction; review of related literature; study area; methodology; results/discussion and lastly findings/conclusion/recommendation.

\section{Related Literature}

Dagnachew (2011) in his research work titled "Road and urban storm water drainage network integration in Addis Ababa" asserted that urbanization along with its impermeable structures is the major cause of flooding in urban areas. Flood disaster is defined in terms of risk to humans and human society, and is seen as a product of the severity and probability of occurrence of flood hazard and the vulnerability of the population/system (Brooks, 2003). McCluskey (2001) identified the following types of flood: predictable flooding, regular flooding; flash flooding; urban flooding and coastal flooding. Long term data on natural disasters suggest that floods and wind storms have been by far the most common causes of natural disaster worldwide over the past 100 years (Few et al., 2004). According to the International Federation of Red Cross and Red Crescent Societies, in 10 years from 1993 to 2002 flood disasters affected more people across the globe (140 million per year on average) than all the other natural or technological disasters put together (IFRC, 2003).

A review of climate change impacts on urbanization by the international institute of environment and development (Huq et al., 2007) found that floods are already having severe impacts on cities, smaller urban centers and rural areas in many African Nations. Examples cited included floods in Mozambique in 2000, heavy rains in East Africa in 2002 that brought floods and mudslides and forced tens of thousands to leave their homes in Rwanda, Kenya, Burundi, Tanzania and Uganda (Huq et al., 2007). With an increasingly urbanizing world, flood disasters are reportedly increasing in urban areas and particularly negatively impacting on poor people and urban development in general (Alam et al., 2008). The magnitude of disaster is not determined by floodwater alone but also by the pattern of vulnerability in which people live. The lives and livelihoods of many poor people are hardest hit by floods. Henderson (2004) and Satterthwaite et al. (2007) asserted that the level of risk and vulnerability in urban areas of developing countries is attributable to socio-economic stress, aging and inadequate physical infrastructure. Nigerian urban areas are typical examples of this high level of risk and vulnerability (Olorunfemi, 2008; Rasheed, 1982). Many risk problems sit at the interface of the natural and social environment, such as flooding, which occurs as a result of the inadequate provision and maintenance of drainage systems, the location of people on marginal sites, and the physical characteristics of an area (Olorunfemi, 2008).

Sultana et al. (2007) asserted that structural measures like embankments can provide protection against many types of flooding. In South and South-east Asia, flood-proofing measures includes raising the plinths or foundations for homesteads, flood shelters and schools (DEC, 2000; Kent et al., 2004). In Bangladesh, one measure that has proved effective is keeping space for livestock in flood shelters (DEC, 2000). Infrastructure is vital for a country's economic development, it is also crucial in improving the quality of life for the poor and mitigation of disasters like urban flood (Straub, 2010; Li, 2010; Brooks, 2010).

\section{Study Area}

The study area is Gombe metropolis, it is located on latitude $10^{\circ} 12^{\prime} \mathrm{N}$ and longitude $11^{\circ} 10^{\prime} \mathrm{E}$. The LGA has an area of $52 \mathrm{~km}^{2}$ and a population of 266,844 persons according to 2006 population census (NPC, 2006), today the population is projected to be 399,531 persons using $3.2 \%$ growth rate (National Population Commission Gombe State Office). Gombe state was created out of the then Bauchi state on $1^{\text {st }}$ October 1991 with its headquarters 
situated in Gombe. It share common borders with Borno, Yobe, Taraba, Adamawa and Bauchi states. Gombe has two distinct seasons, the dry season (November-March) and the rainy season (April-October) with an average annual rainfall of $132.2 \mathrm{~cm}$. A large part of the existing town is at the foot of the Akko escarpment and on a shallow dish-like site. However, there is a westward expansion of the town up-hill the escarpment.

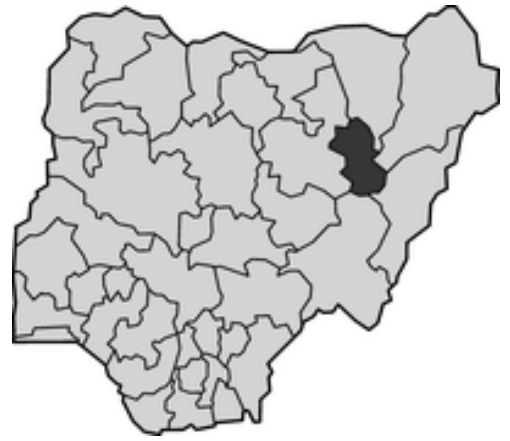

Figure 1. Map of Nigeria showing Gombe State

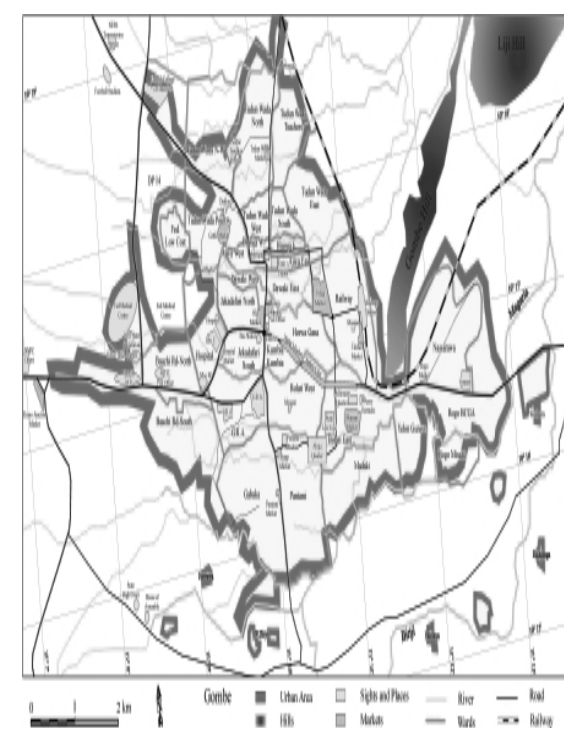

Figure 3. Map showing overview of Gombe metropolis

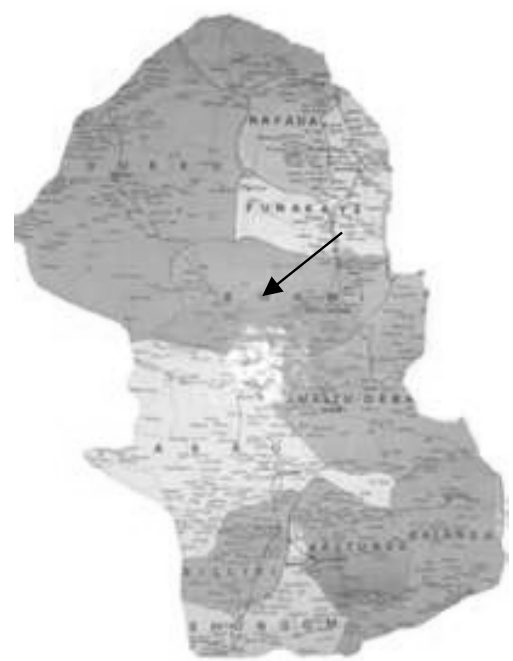

Figure 2. Map of Gombe State showing the study area

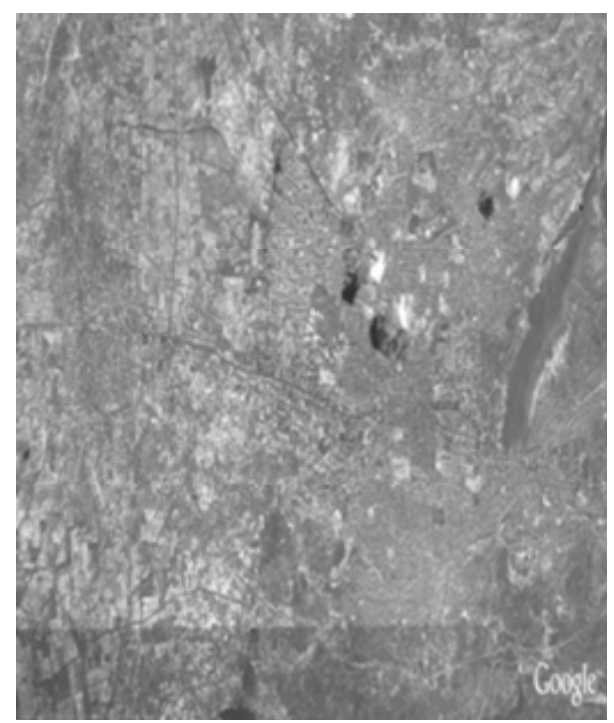

Figure 4. An a erial map showing Gombe metropolis

\section{Methodology}

In this study, the survey research design was used to collect data from the study area. The targeted population for this study consisted of 1,923 households in flood prone areas in Gombe metropolis. 13\% of the population was used as sample size as this percentage gives a fair representation of the entire population. The stakeholders involved cut across civil servants, business men/women, and farmers. The sampled areas included: GRA, Pantami, Burundi, Checheniya, Federal lowcost, Jekadafari, Herwagana, Jankai and Tudun Wada. The stratified sampling technique was adopted for sampling. Two sources of data i.e. (primary and secondary) were used to collect data from the field. The primary data were sourced through personal observations, structured and unstructured interviews, as well as a structured questionnaire (250 questionnaires were administered on family heads in the study area; however, only 237 questionnaires were retrieved). Secondary data were sourced from documented materials. The study involves two variables i.e. the criterion variable (flood disaster) and the 
predictor variables (urban infrastructure). Simple statistical tools such as tabulation, percentages and charts were used in the analysis of the collated data. Spearman's rank correlation and multiple linear regression analysis were also carried out to determine the relationship between the criterion and predictor variables.

\section{Results and Discussion}

This section presents the results obtained from analysis of field data and discusses the result.

Table 1. Responses on inadequacy of urban infrastructure in Gombe

\begin{tabular}{cccc}
\hline Urban Infrastructure & No. of respondents & Percentage no. of respondents & Ranking \\
\hline Drainages & 114 & 48.1 & 1 \\
Refuse Dumps & 69 & 29.1 & 2 \\
Good Layout Plan & 54 & 22.8 & 3 \\
Total & 237 & 100.0 & \\
\hline
\end{tabular}

Source: Field Survey 2011.

From Table 1 above, inadequacy of drainage facilities is ranked the number one factor that is responsible for flood disaster in Gombe (48.1\%), followed by refuse dumps (29.1\%), and then lack of good layout plan (22.8\%). An improvement in the provision of drainages, refuse dumps and a good layout plan will help in the mitigation of flood disaster in Gombe.

Table 2. Type of drainage

\begin{tabular}{cccc}
\hline Type of Drainage & Frequency & Percent & Cumulative Percent \\
\hline Reinforced Concrete Cast & 30 & 12.7 & 12.7 \\
Sand Crete Blocks & 40 & 16.9 & 29.5 \\
Natural & 53 & 22.4 & 51.9 \\
No Drainage & 114 & 48.1 & 100.0 \\
Total & 237 & 100.0 & \\
\hline
\end{tabular}

Source: Field Survey, 2011.

Most drainages in Gombe metropolis are natural drainages (22.4\%), with the exception of few artificially constructed ones (12.7\% reinforced concrete cast and $16.9 \%$ sand Crete blocks) as is seen in Table 2 . The artificial drainages are mostly constructed by the sides of road networks. The artificially constructed drainages are projects that were carried out by UNDP and the World Bank in 2000, and 2005/2006 respectively. This effort was to assist the state in the control and abatement of flood in Gombe metropolis. However, investigation revealed that the sizes and volume (carrying capacities) of these drainages are inadequate. Hence, even moderate rains produce storm water that exceeds the capacities of these drainages, thereby resulting to flood incidences.

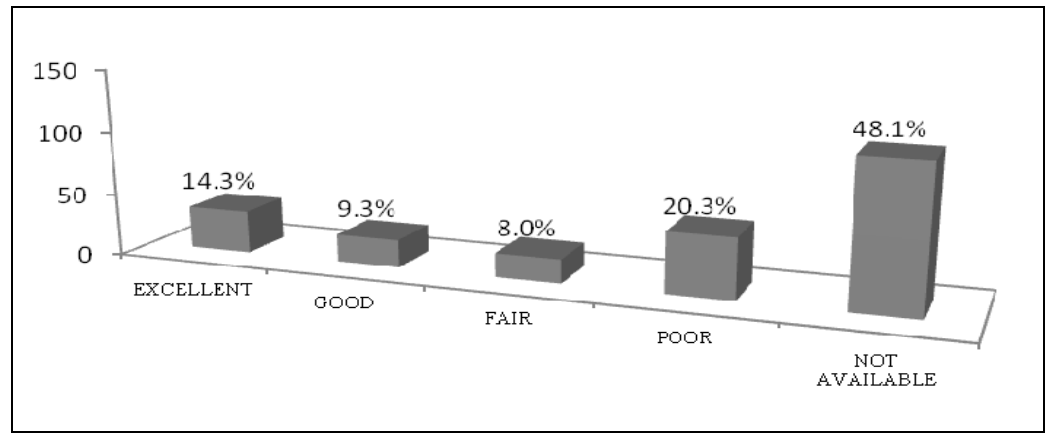

Figure 5. Condition of drainage facilities 
Figure 5 shows the present condition of drainage facilities in the metropolis. It is evident from the responses above that most of the drainages are in bad condition. Only few of them (14.3\% in excellent condition and 9.3\% in good condition) are satisfactorily functional and in good condition. However, $48.1 \%$ of the respondents indicated that there are no drainage infrastructures in their areas. In the fight against urban flooding in Gombe metropolis, it is imperative that the fight begins with the maintenance of the available drainage facilities in the metropolis, by means of making them functional and in good condition all the time, most especially during rainy seasons. Also Building on drainage channels (see Figure 9) should be seriously checked and discouraged.

Table 3. Distance of property from drainage

\begin{tabular}{cccc}
\hline Distance of Property from Drainage & Frequency & Percent & Cumulative Percent \\
\hline ONE METER & 8 & 3.4 & 3.4 \\
TWO METERS & 30 & 12.7 & 16.0 \\
THREE TO FIVE METERS & 60 & 25.3 & 41.4 \\
SIX TO TEN METERS & 50 & 21.1 & 62.4 \\
ABOVE TEN METERS & 89 & 37.6 & 100.0 \\
Total & 237 & 100.0 & \\
\hline
\end{tabular}

Source: Field Survey 2011.

Most of the buildings (62.4\%) in the study area are within the ranges of 1 and 10 meters from drainages. This is against the stipulated $25 \mathrm{~m}$ to $50 \mathrm{~m}$ set back as is contained in the Town Planning Laws. These could be one of the reasons why many residents are affected by flood disaster almost every year. Storm water that could have drained in nearby soil finds its way easily into people's buildings.

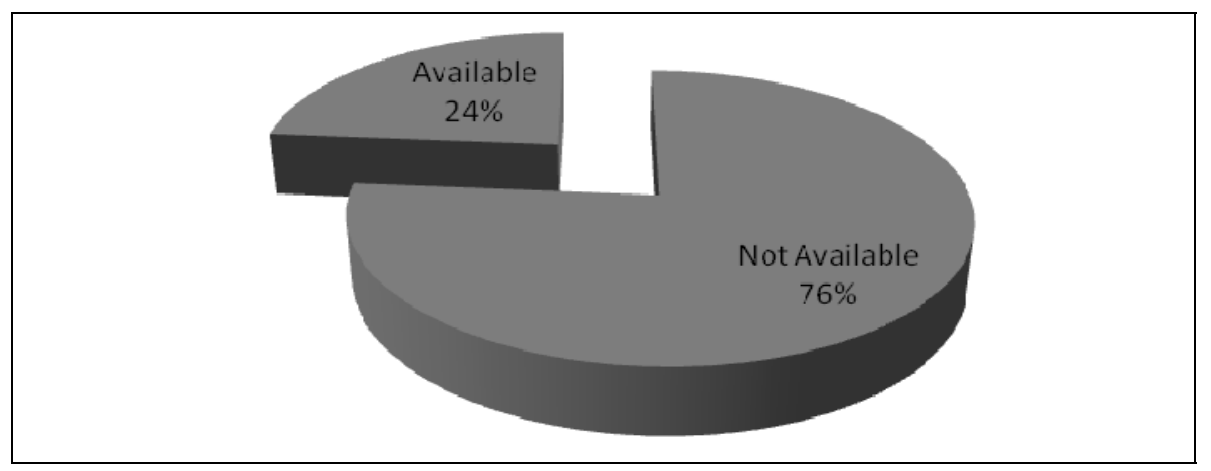

Figure 6. Availability of layout plan

From Figure 6, 24\% of the respondents indicated the availability of a layout plan in their areas while $76 \%$ of the respondents indicated that there are no layout plans in their areas. However, secondary data revealed that, there are instances where there are layout plans on paper but it has not been interpreted on the ground, most especially in areas like Federal Low-cost and Checheniya. This is, as a result of the fact that, government failed to pay compensation to the original owners of the land, in view of the above, land owners resort to selling their property indiscriminately without any good layout in place. 


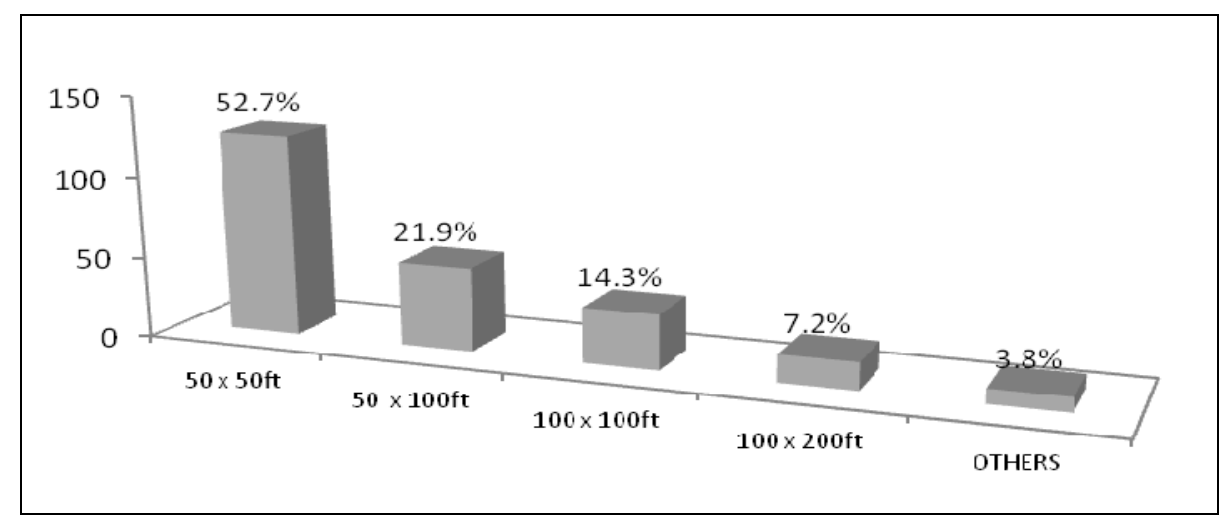

Figure 7. Plot sizes (In feet)

Note 1 . feet $=0.3048$ meter

Investigations revealed that majority of the residents in the study area are occupying $15.24 \mathrm{~m} \times 15.25 \mathrm{~m}$ plot sizes (52.7\% of the population). While $21.9 \%$ and $14.3 \%$ are occupying $15.25 \mathrm{~m} \mathrm{x} 30.48 \mathrm{~m}$ and $30.48 \mathrm{~m} \times 30.48 \mathrm{~m}$ plot sizes respectively. $7.2 \%$ of the population are occupying $30.48 \mathrm{~m} \times 60.96 \mathrm{~m}$ plot sizes; which are mostly located at G. R. A. and Federal Low-cost areas. Furthermore, setbacks to property lines that would have demarcated areas liable to flood and other related hazards are built upon. In view of the culture and traditional practices in this part of the country where we have households within compounds, these types of plot sizes are grossly inadequate. By implication, developers are constrained not to leave any set back as provided in the Town Planning Laws. Hence, plots are usually developed fully without leaving any space that may allow infiltration of rainwater. Therefore, rain falls directly on either rooftops or hard surfaces that eventually flow out into the streets. The cumulative effect of these usually leads to water flowing on access roads and footpaths and depending on the intensity and the duration of the rain, flooding is in most cases inevitable.

Table 4. Condition of refuse dump

\begin{tabular}{cccc}
\hline Condition & Frequency & Percent & Cumulative Percent \\
\hline EXCELLENT & 23 & 9.7 & 9.7 \\
GOOD & 76 & 32.1 & 41.8 \\
FAIR & 66 & 27.8 & 69.6 \\
POOR & 3 & 1.3 & 70.9 \\
NOT AVAILABLE & 69 & 29.1 & 100.0 \\
Total & 237 & 100.0 & \\
\hline
\end{tabular}

Source: Field Survey, 2011.

From Table 4, only $9.7 \%$ and $32.1 \%$ of the available refuse dumps are in excellent and good conditions respectively. $29.1 \%$ of the respondents indicated that there are no provisions of refuse dumps in their areas. Due to gross inadequacy of refuse dumps in the metropolis, people resort to indiscriminate dumping of refuse on drainage channels (see Figure 8). These blocks the drainages and in the event of rainfall, the water overflows the drainages resulting to flood and subsequently destruction of lives and properties. 


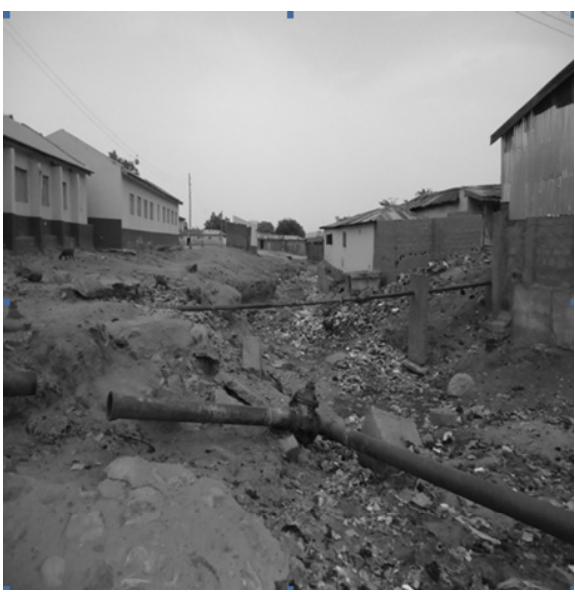

Figure 8. Indiscriminate dumping of refuse

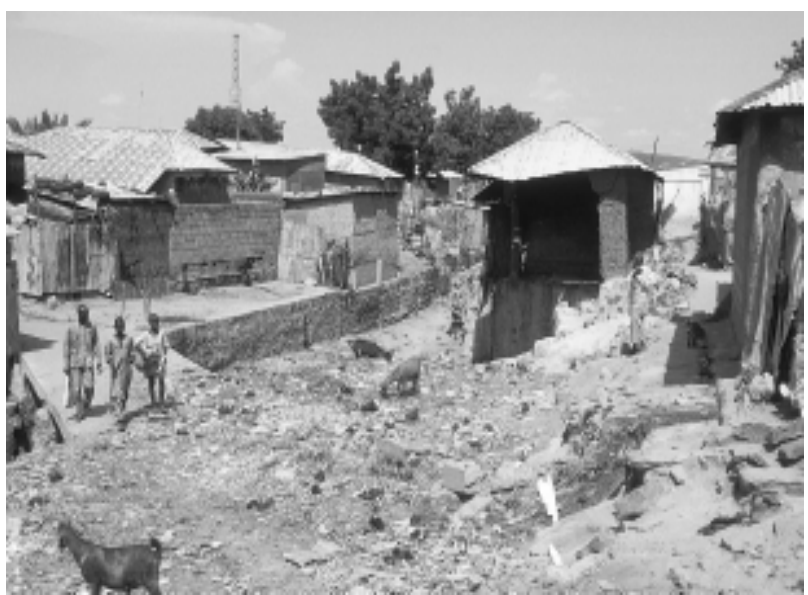

Figure 9. Building on drainage channels

Table 5. Annual/ monthly rainfall figures of Gombe 2000-2011

\begin{tabular}{|c|c|c|c|c|c|c|c|c|c|c|c|c|c|}
\hline \multirow[t]{2}{*}{ Month } & \multicolumn{12}{|c|}{ Year } & \multirow[t]{2}{*}{ Mean } \\
\hline & 2000 & 2001 & 2002 & 2003 & 2004 & 2005 & 2006 & 2007 & 2008 & 2009 & 2010 & 2011 & \\
\hline \multicolumn{14}{|l|}{ JAN. } \\
\hline \multicolumn{14}{|l|}{ FEB. } \\
\hline \multicolumn{14}{|l|}{ MARCH } \\
\hline APRIL & 20.7 & 19.6 & 20.15 & 40.3 & 14 & 66.7 & & 19.5 & 14.7 & & 18.9 & & 26.1 \\
\hline MAY & 7.5 & 80.7 & 44.1 & 31.6 & 63 & 0.3 & 70.1 & 54.9 & 125 & 147.3 & 122.5 & 73.7 & 68.4 \\
\hline JUNE & 157.8 & 92 & 124.7 & 107.4 & 66.3 & 148.6 & 144.5 & 118.4 & 109.9 & 136.0 & 144.2 & 117.4 & 122.2 \\
\hline JULY & 236.5 & 235.2 & 235.8 & 203.9 & 268.5 & 139.3 & 221.3 & 259.4 & 107.3 & 159.6 & 187.4 & 130.2 & 198.7 \\
\hline AUG. & 238.7 & 272.4 & 255.5 & 387.6 & 435.4 & 339.9 & 175.6 & 271.8 & 347.6 & 220.1 & 182.0 & 237.2 & 280.3 \\
\hline SEPT. & 131.7 & 181.6 & 156.6 & 159.1 & 136.4 & 181.7 & 264.7 & 141.9 & 194.3 & 159.0 & 122.3 & 120.8 & 162.5 \\
\hline OCT. & 11.3 & 28.9 & 20.1 & 52.8 & 22.0 & 83.6 & 28.9 & & 72 & 67.3 & 64.8 & 76.0 & 48 \\
\hline NOV. & & & & & & 8.2 & & & & & & & 8.2 \\
\hline DEC. & & & & & & & & & & & & & \\
\hline $\begin{array}{l}\text { Mean } \\
\text { Annual } \\
\text { Rainfall }\end{array}$ & 114.88 & 130.06 & 122.42 & 140.38 & 143.65 & 121.04 & 150.85 & 144.3 & 124.83 & 148.21 & 120.3 & 125.8 & \\
\hline$(\mathrm{cm})$ & & & & & & & & & & & & & 132.2 \\
\hline
\end{tabular}

Source: Federal Ministry of Aviation, Meteorology Unit, Gombe.

Gombe is located within the Sub-Sudan climate zone. It is characterized by two distinct seasons: dry season (November to March) and wet season (April to October). The highest rainfall is recorded in August as shown in Table 5 above with a mean annual rainfall of $280.3 \mathrm{~cm}$. The lowest rainfall is recorded in November with a mean annual rainfall of $8.2 \mathrm{~cm}$. From the table above, it can be seen that the amount of rain fall in the study area is quite moderate (annual mean rainfall of $132.2 \mathrm{~cm}$ ). Indicating that flooding in the area is not necessarily the function of heavy downpour. 
Table 6. Flood frequency

\begin{tabular}{cccc}
\hline Frequency of flood & Frequency & Percent & Cumulative Percent \\
\hline Every Month Of The Season & 24 & 10.1 & 10.1 \\
Every Year & 145 & 61.2 & 71.3 \\
Once In Two Years & 34 & 14.3 & 85.7 \\
None At All & 19 & 8.0 & 93.7 \\
Others & 15 & 6.3 & 100.0 \\
Total & 237 & 100.0 & \\
\hline
\end{tabular}

Source: Field survey, 2011.

Flood incidences have become a perennial problem in Gombe metropolis. Table 6 above showed that every year residents in Gombe metropolis experience flood during the wet seasons (as indicated by $61.2 \%$ of the respondents). Even though the average annual rainfall figure $(132.2 \mathrm{~cm})$ is moderate, yet every year there is a record of flood incidence in the study area. This is a clear indication that, it is not high amount of rainfall that is responsible for flood disaster in Gombe; rather it is the direct result of negative influence of urbanization dynamics without corresponding urban infrastructure put in place (see Table 1 and Figures 8 and 9).

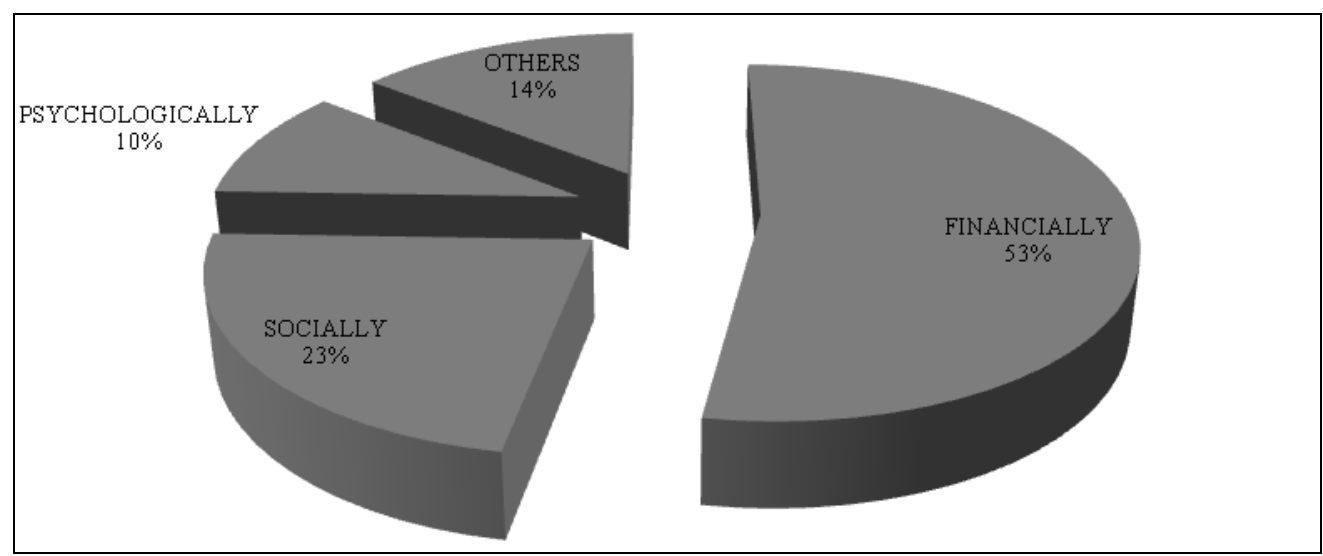

Figure 10. Effects of flood disaster

The effects of flood disaster in Gombe metropolis is becoming more worrisome to residents living within the town. From Figure 10 above, 53\% of the respondents indicated that they were affected by flood disasters financially, $23 \%$ and $10 \%$ were affected socially, and psychologically respectively. The incidences of flood disasters in Gombe had devastating impact on the residents not only financially, but also socially and psychologically. 


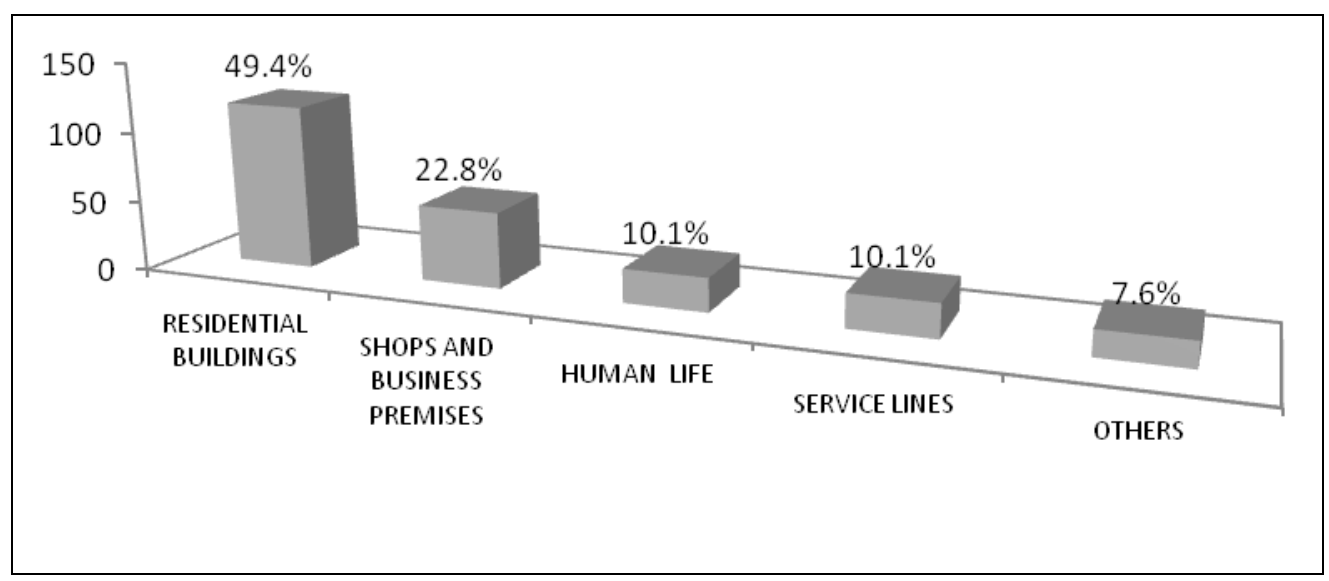

Figure 11. Destruction by flood

From Figure 11, 49.4\% of the respondents had their residential buildings destroyed by flood; the shops and business premises of $22.8 \%$ of the respondents were destroyed by flood, $10.1 \%$ of the respondents lost their loved ones as a result of flood disaster in Gombe metropolis. Almost every year, many lives and properties worth millions of naira is lost to flood disaster in Gombe. The August $20^{\text {th }} 2004$ flood was the worst flood disaster experienced in Gombe metropolis since the creation of the state in 1996. The State Emergency Management Agency (SEMA) reports that over 120 people were reported dead, while many houses were swept away completely and several others collapsed. As a result, several thousands of families were rendered homeless. Many shops were destroyed and roadside drainages were blocked by silt and sand. Some roads were rendered impassable as heavy deposits of sand covered everywhere. Vehicular traffic was disrupted for few days. Service lines such as PHCN poles, NITEL lines and Water pipes were badly affected.

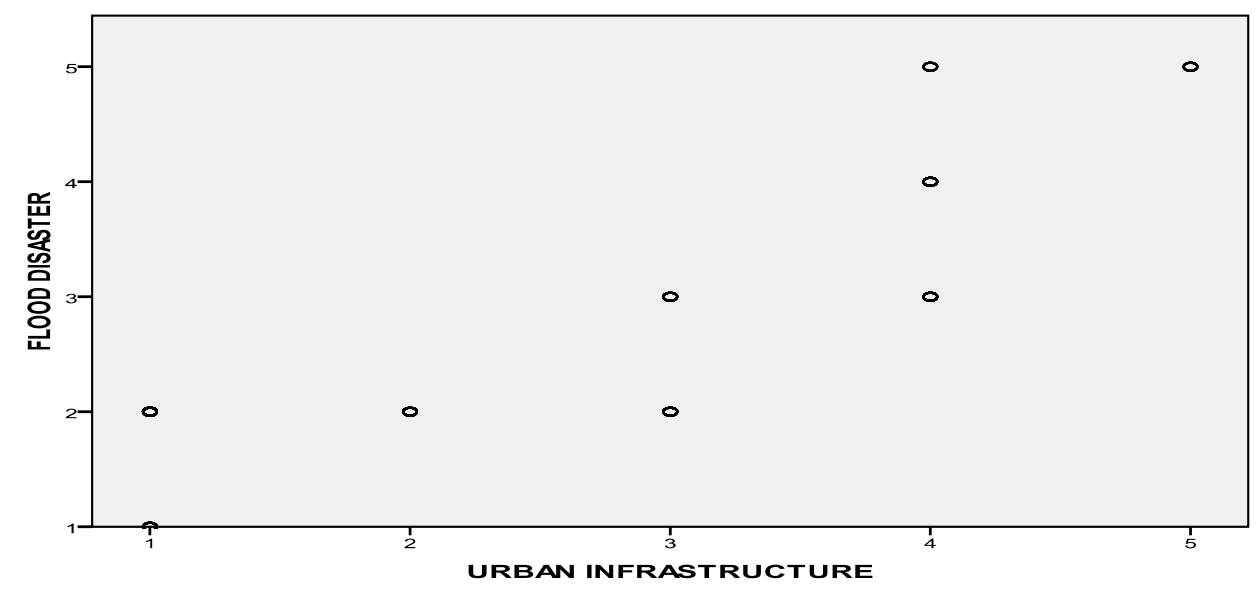

Figure 12. Relationship between flood incidence and urbanization dynamics

The scarttergram above reveals that there is a positive linear relationship between urban infrastructure and flood disaster in the study area. 
Table 7. Correlation analysis

\begin{tabular}{ccccc}
\hline & & & FLOOD & URBAN \\
& & & DISASTER & INFRASTRUCTURE \\
\hline & FLOOD DISASTER & Correlation Coefficient & 1.000 & $.792^{* *}$ \\
\multirow{3}{*}{$\begin{array}{c}\text { Spearman's } \\
\text { rho }\end{array}$} & & Sig. (2-tailed) &. & .000 \\
& & $\mathrm{~N}$ & 237 & 237 \\
& URBAN & Correlation Coefficient & $.792^{* *}$ & 1.000 \\
& INFRASTRUCTURE & Sig. (2-tailed) & .000 &. \\
\hline
\end{tabular}

Source: Analysis of survey data, 2011.

The correlation coefficient between urban infrastructure and flood disaster in the study area is 0.792 indicating a strong positive correlation. This correlation is significant at the 0.01 level (2-tailed) of significance as indicated by a $\mathrm{p}$ value of 0.000 . This implies that a significant improvement in the provision and maintenance of urban infrastructure in the metropolis will significantly mitigate the incidences of flood disasters in the study area.

Table 8. Regression model summary

\begin{tabular}{ccccc}
\hline Model & R & R Square & Adjusted R Square & Std. Error of the Estimate \\
\hline $.936^{\mathrm{a}}$ & .876 & .874 & .352
\end{tabular}

Source: Analysis of survey data, 2011.

Table 8 shows the regression model summary result, which indicates a high positive correlation (0.936) between the variables.

Table 9. ANOVA (Analysis of Variance)

\begin{tabular}{cccccc}
\hline Model & Sum of Squares & df & Mean Square & F & Sig. \\
\hline Regression & 201.584 & 4 & 50.396 & 378.103 & $.000^{\mathrm{a}}$ \\
Residual & 30.922 & 232 & .133 & & \\
Total & 232.506 & 236 & & & \\
\hline
\end{tabular}

Source: Analysis of survey data, 2011.

Table 9 tests the overall significance of the coefficients ( $\beta$ 's). The results indicated that the overall model is statistically significant, $[\mathrm{F}(4,232)=378.103, \mathrm{P}=0.000]$.

Table 10. Coefficients

\begin{tabular}{|c|c|c|c|c|c|}
\hline \multirow{2}{*}{ Model } & \multicolumn{2}{|c|}{ Unstandardized Coefficients } & \multirow{2}{*}{$\begin{array}{c}\text { Standardized Coefficients } \\
\text { Beta }\end{array}$} & \multirow{2}{*}{$\mathbf{t}$} & \multirow{2}{*}{ Sig. } \\
\hline & $\mathrm{B}$ & Std. Error & & & \\
\hline (Constant) & 1.121 & .081 & & 13.794 & .000 \\
\hline PLOT SIZE & .671 & .037 & .768 & 18.361 & .000 \\
\hline DRAINAGE & -.023 & .008 & -.070 & -2.848 & .005 \\
\hline REFUSE DUMP & .240 & .029 & .332 & 8.288 & .000 \\
\hline LAYOUT PLAN & -.436 & .064 & -.219 & -6.851 & .000 \\
\hline
\end{tabular}

Source: Analysis of survey data, 2011. 
In Table 10, the result reveals that, all the predictors (plot size, drainage, refuse dump and layout plan) significantly predicts flood disaster in the study area, with $\mathrm{t}=18.361, \mathrm{p}=0.000<0.01 ; \mathrm{t}=-2.848, \mathrm{p}=0.005<0.01$; $\mathrm{t}=8.288, \mathrm{p}=0.000<0.01 ;$ and $\mathrm{t}=-6.851, \mathrm{p}=0.000<0.01$ for plot size, drainage, refuse dump and layout plan respectively.

The regression equation adopted was $\mathrm{Y}=\mathrm{X} 1+\mathrm{X} 2+\mathrm{X} 3+\mathrm{X} 4 \ldots \ldots \ldots \mathrm{Xn}$. Where:

$\mathrm{Y}$ is flood disaster in Gombe metropolis

$\mathrm{X} 1$ is plot size

$\mathrm{X} 2$ is drainage

$\mathrm{X} 3$ is refuse dump

$\mathrm{X} 4$ is layout plan

The regression equation therefore is: $Y=1.121+0.671 X_{1}+(-0.023) X 2+0.240 X_{3}+(-0.436) X 4$.

Which can be presented as $Y=1.121+0.671$ (plot size) -0.023 (drainage) $+0,240$ (refuse dump) -0.436 (layout plan).

\section{Findings, Conclusion and Recommendation}

The study revealed that contrary to the general assumption that heavy rainfall is the major cause of urban flooding (which mostly results into destruction of lives and properties), lack of adequate urban infrastructure such as: drainage facilities, refuse dumps and good layout plan are the major factors responsible for flood disaster in Gombe metropolis. The researchers conclude that placement of appropriate urban infrastructure in the metropolis will drastically mitigate flood disasters in Gombe. The study recommends improvement on the maintenance of the available drainage infrastructure in the metropolis and the integration of solid waste management to prevent over flowing of flood as a result of blockage of drains. Taking advantage of the sloppy nature of the topography in the metropolis, it was also recommended that starting from Tumfure area, along the Akko slope to Sabon-Layi of the Gombe catchment area, construction of large drainages could effectively reduce the surface run-off during a strong rainfall event. Government at all tiers should intervene by making available funds for appropriate urban infrastructures to be put in place. A paradigm shift of the behavioral pattern of the Gombe urban community (with respect to indiscriminate dumping of refuse, building on drainage channels and flood prone areas, building without leaving appropriate setbacks, poor maintenance culture, etc) is very crucial to the mitigation of flood disaster in the study area.

\section{References}

Alam, K., Herson, M. O., \& Donnel, I. (2008). Flood Disasters: Learning from Previous Relief and Recovery Operations. Provention Consortium and ALNAP.

Bond Gary. (1994). Survey of Developing Country Infrastructure Projects. Washington DC: World Bank.

Brooks, D. H. (2010). Asia's Infrastructure and Trade. Presentation given at the conference "The Economics of Infrastructure in a Globalised World: Issues, Lessons and Future Challenges," Sydney, 18-19 March. Retrieved March 7, 2012, from http://cama.anu.edu.au/Infrastructure_Conference.asp

Brooks, N. (2003). Vulnerability, risk and adaptation: A conceptual framework. Tyndal Center for Climate Change Research working Paper 38 (pp. 20).

Chandavarkar, A. (1994). Infrastructure Finance: Issues, Institutions and Policies. Washington DC: World Bank.

Dagnachew, A. B. (2011). Road and urban storm water drainage network integration in Addis baba: Addis Ketema Sub-city. Journal of Engineering and Technology Research, 3(7), 217-225. Retrieved March 1, 2012, from http://www.academicjournals.org/jetr/PDF/pdf\%202011/Jul/Belete.pdf

DEC. (2000). Bangladesh 1998 Flood Appeal - An independent evaluation. Final report. London: Disasters Emergency Committee. Retrieved from apps.odi.org.uk/erd/ReportDetail.aspx?reportID=2859

Few, R., Ahern, M., Matthies, F., \& Kovats, S. (2004). Floods, Health and Climate Change: A Strategic Review. Working Paper No. 63. Tyndall Centre for Climate Change Research.

Govt. of India. (1996). The India Infrastructure Report: Policy Imperatives for Growth and Welfare. New Delhi: Ministry of Finance.

Henderson, L. J. (2004). Emergency and Disaster: Pervasive Risk and Public Bureaucracy in Developing 
Nations. Public Organization Review: A Global Journal, 4, 103-119.

Huq. S., Kovats, S., Reid, H., \& Satterthwaitte, D. (2007). Editorial: Reducing Risks to Cities from Disasters and Climate Change. Environment and Urbanization, 19(1), 3-15. http://dx.doi.org/10.1177/0956247807078058

IFRC. (2003). World Disaster Report (Geneva: IFRCRCS). Retrieved January 9, 2012, from www.ifrc.org

IPCC. (2007). Fourth Assessment Report. Geneva: Intergovernmental Panel on Climate Change. Retrieved February 8, 2012, from www.ipcc.ch

Jha Raghabendra. (1995). Policy Change Agenda for Urban Infrastructure Finance. New Delhi: National Institute of Urban Affairs.

Kent, H. et al. (2004). Linkages between flood and drought disaster in Cambodia and rural Livelihood and food security. International Federation of Red Cross and Red Crescent Societies and the Cambodian Red Cross Society.

Kohli, H. (1995). Infrastructure Development in Asia and Pacific: Toward A New Public-Private Partnership. Washington DC: World Bank.

Li, Zhigang. (2010). Some evidence on the performance of transport infrastructure investment in China, presentation given at the conference "The Economics of Infrastructure in a Globalised World: Issues, Lessons and Future Challenges," Sydney, 18-19 March. Retrieved March 7, 2012, from http://cama.anu.edu.au/Infrastructure_Conference.asp

McCluskey, J. (2001). Water supply, health and vulnerability in floods. Waterlines, 19(3), 14-17.

Nayak, P. (1999). Infrastructure: Its Development and Impact on Agriculture in North-East India. Journal of Assam University, IV(1), 59-65.

NPC. (2006). Population and Housing Census of the Federal Republic of Nigeria. Priority Tables (LGA) National Population Commission Volume II.

Olorunfemi, F. B. (2008). Disaster Incidence and Management in Nigeria. Research Review, 24(2), 1-23.

Rasheed, H. (1982). Urban Flood Problems in Benin City Nigeria, Natural or Man-Made? Malaysia Journal of Tropical Geography, 6(4), 17-30.

Satterthwaite, D., Saleemul, H., Mark, P., Hannah, R., \& Patricia, R. (2007). Adapting to Climate Change in Urban Areas The possibilities and constraints in low-and middle-income nations. Human Settlements Discussion Paper Series.

Straub, Stéphane. (2010). Infrastructure and Development, presentation given at the conference "The Economics of Infrastructure in a Globalised World: Issues, Lessons and Future Challenges," Sydney, 18-19 March. Retrieved March 7, 2012, from: http://cama.anu.edu.au/Infrastructure_Conference.asp

Sultana, P. et al. (2007). Can England Learn Lessons from Bangladesh in Introducing Participatory Floodplain Management? Water Resources Management, 22(3), 357-376. Retrieved December 13, 2011, from www.springerlink.com 